Computers in

Botanical Collections 


\section{Computers in Botanical Collections}

Edited by

J. P. M. Brenan

Royal Botanical Gardens

Kew, England

R. Ross

British Museum (Natural History)

London, England

and

J. T. Williams

University of Birmingham

Birmingham, England

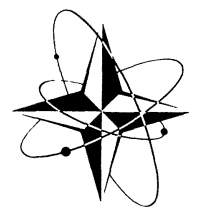

Published in coordination with NATO Scientific Affairs Division by 
Proceedings of an international conference, sponsored by NATO, on The Use of Electronic Data Processing: Major Plant Taxonomic Collections, held at Kew in October 1973

Library of Congress Catalog Card Number 75-9386

ISBN-13: 978-1-4684-2159-0 e-ISBN-13: 978-1-4684-2157-6

DOI: $10.1007 / 978-1-4684-2157-6$

(C) 1975 Plenum Press, London,

Softcover reprint of the hardcover 1st edition 1975

A Division of Plenum Publishing Company, Ltd.

Davis House, 8 Scrubs Lane, Harlesden, NW10 6SE, England

U.S. edition published by Plenum Press, New York

A Division of Plenum Publishing Corporation

227 West 17th Street, New York, N.Y. 10011

\section{All Rights Reserved}

No part of this book may be reproduced, stored in a retrieval system, or transmitted, in any form or by any means, electronic, mechanical, photocopying, microfilming, recording or otherwise, without written permission from the Publisher 


\section{P R E F A C E}

This volume records the proceedings of, and the papers read at, an international conference to consider the use of electronic data processing methods in the major taxonomic plant collections of Europe, primarily herbaria but also living collections. This conference took place at the Royal Botanic Gardens, Kew, from 3rd to 6th October, 1973. It was attended by some 90 delegates, observers and speakers, mainly from a wide range of the major European herbaria, but also from other interested institutions.

The problem to be discussed was a big one. Taxonomic collections of the sorts mentioned above constitute the main centres for the scientific documentation of the flora of the world. With the extinction of so many species more or less imminently threatened, and with the modification or disappearance of so many vegetation types through the activities of man, the information contained in these collections grows in importance. Their aggregate size, in Europe, has been estimated at between 50 and 100 millions, and these are annually augmented at a rapid rate. Each specimen or living plant comprises a source of evidence and information represented both by the specimen itself and the associated information provided by the collector and subsequent investigators - identifications, field notes, records of subsequent research, etc. This associated information is known as the label data.

Research on the taxonomy and geographical distribution of plants usually requires data from specimens stored in a number of institutions in different countries. At present it is difficult or impossible to survey this information completely.

It is now feasible, with the help of large computers, to compile comprehensive catalogues of much of this information, and to make it more widely available in the form of tapes or print-out. There is, however, the danger that, by independent action, institutions may adopt incompatible systems which can result in the stored information becoming unavailable internationally. 
Considerable progress has been made in the United States, but in Europe, where perhaps the majority of major herbaria are located, progress in the application of E.D.P. methods in herbaria has been hitherto slight. Furthermore, most schemes have been concerned with relatively small samples - up to 50,000 to 100,000 items. Major schemes, even if desirable, have been too demanding in time, money and staff. The problem remains, however, and increases rather than diminishes, but funding through the international agencies may represent a future solution.

It was to study the scope of E.D.P methods in the major collections and to give an impetus to their application in Europe that this conference was held. It should be made clear that the objective was to discuss problems connected with the storage and retrieval of label data, and not the handling of taxonomic data for such purposes as numerical taxonomy, mechanised key construction, automated identification, etc.

The conference was made possible by financial support from the Eco-Sciences Panel of NATO, to whom our thanks are due. Gratitude is also owed to Dr. Andreas Rannestad, Secretary of the Eco-Sciences Panel, who was an unfailing source of help and advice during the organisation of the conference and who represented NATO at the meeting itself.

The organisation of the conference was carried out by an Organising Committee constituted as follows: Professor J.G. Hawkes (University of Birmingham), Chairman; Mr. J. P. M. Brenan(Royal Botanic Gardens, Kew); Mr. D.M. Henderson (Royal Botanic Garden, Edinburgh); Dr. F.H. Perring or Miss D.M. Scott (Biological Records Centre, Monks Wood); Mr. R Ross or Mr. T.F.M. Cannon (British Museum, Natural History); and Dr. T. Williams (University of Birmingham).

The Organising Committee was ably assisted by a Secretariat drawn from the Royal Botanic Gardens, Kew: Mr. D. Field, Miss S. Howard, Mrs. H. Hyde, Mrs. S. Kozdon, and Mr. E. Timbs.

After the conference, a brief resume of the proceedings was published in Nature 246: 62 (November 9, 1973) and a fuller account, with abstracts of the papers, in Taxon 23 (1): 101-107 (February, 1974).

As NATO generously offered to publish a full account of the conference, an Editorial Committee (Mr. J.P.M. Brenan, Professor J.G. Hawkes, Mr. R. Ross and Dr. T. Williams) was appointed by the Organising Committee and the present volume is the result. 
Thanks are due to the speakers for kindly providing texts of these contributions. Unfortunately three papers have had to be printed in abstract only.

Thanks are also due to the many other people who contributed in a variety of ways towards the smooth running of the conference. I would like to express particular thanks to those who helped in the recording of the discussions: Mr. D.V. Field, Mr. J. Warrington and Dr. W.D. Clayton; also, finally, to my co-editors.

J. P. M. Brenan 


\section{CONTENTS}

page

Preface........................... v

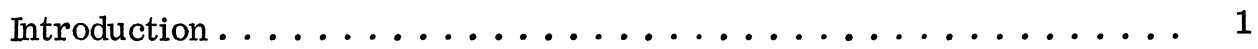

J. G. Hawkes

Introduction ......................... 5

A. Rannestad

E. D. P. in Major Herbaria - The Priorities . . . . . . . . . . 9 J.P. M. Brenan

The Data from Herbaria. . . . . . . . . . . . . . . . 17

D. M. Henderson

Discussion, Morning, Wednesday 3 October ............. 25

Relations Between Herbarium Records and Other Records . . . . . . 27 R. Ross

Electronic Data Processing of Herbarium Specimens

Data for the Flora of Veracruz Program. . . . . . . . . . . . . 35

A. Gomez-Pompa, J. A. Toledo and M. Soto

The Uses of Electronic Data Processing for Herbarium Specimen

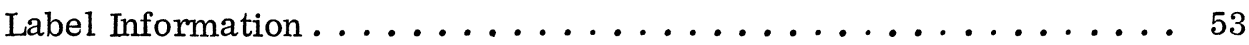
A. V. Hall

Discussion, Afternoon, Wednesday 3 October ............ 61

The Flora North America Information System _... . . . . . . 67

S. G. Shetler

Electronic Data Processing in the Herbarium . . . . . . . . . . 69

F. H. Perring

The Data Bank of the British Antarctic Survey's Botanical Section . 79

D. M. Greene and S. W. Greene

Discussion, Morning, Thursday 4 October . . . . . . . . . . 89 
American Horticultural Society Plant Records Centre. . . . . . . .

R. A. Brown

Data Standards for Collection-Holding Organisations. . . . . . . .

J. L. Cutbill

Information Management and Use of TAXIR in Herbaria . . . . . .

D. J. Rogers

The Use of the SELGEM System in Support of Systematics . . . .

J. F. Mello

Discussion, Afternoon, Thursday 4 October .

The Application of Electronic Data Processing to the Mapping of Plant Distributions .......................

J. H. Soper

The Living Plant Record System at the Royal Botanic Garden,

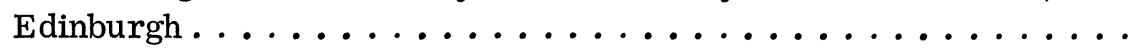

J. Cullen

The Use of E. D. P. in Zoological Collections . . . . . . . . . .

D. B. Williams

Discussion, Friday, 5 October, at End of Morning ........

Discussion, Morning, Saturday 6 October ............ 181

Supplementary Notes on Taxonomic Information In Relation to

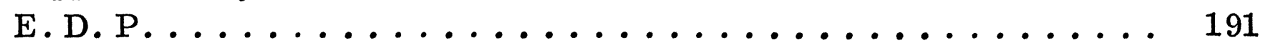

J. G. Hawkes

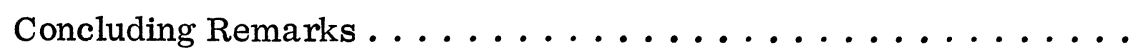

J. Heslop-Harrison

Resolutions Passed by the Conference

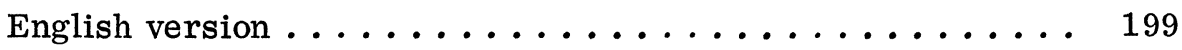

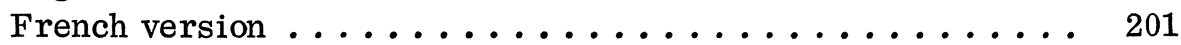

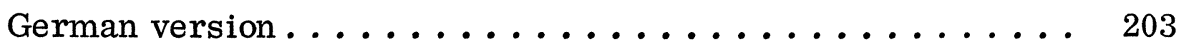

List of Contributors . . . . . . . . . . . . . . . . . 205

List of Participants . . . . . . . . . . . . . . . . . 207

Subject Index . . . . . . . . . . . . . . . . . . . . 213 